\title{
Influence of Thermal Boundary on the Problems of Thermal Stress Cleaving
}

\author{
Akihide SAIMOTO*3, Yasufumi IMAI and Fumitaka MOTOMURA \\ ${ }^{* 3}$ Graduate School of Science and Technology, Nagasaki University, \\ 1-14 Bunkyo-machi, Nagasaki-shi, Nagasaki, 852-8521 Japan
}

\begin{abstract}
A closed-form expression of the stress intensity factor is derived for a problem of straight crack in an infinite plate under thermal stresses induced by a temperature rise at an infinitesimal area. The present solution is applicable to wide range of uncoupled thermoelastic problems and is especially useful to understand the mechanical behavior of cracks in thermal stress cleaving (TSC). For instance, the present solution is useful for the prediction of an optimal temperature distribution in TSC, which is a function of various conditions such as shape of the plate, crack path, cleaving velocity and so on. Some basic problems of TSC formerly analyzed by the use of thermoelastic fields induced by a heat source were examined to confirm the applicability of the present solution.
\end{abstract}

Key Words : Elasticity, Thermal Stress, Fracture Mechanics, Thermal Stress Cleaving, Uncoupled Problem, Complex Variable Method, Body Force Method

\section{1. 緒言}

熱応力でき裂進展を制御して材料を切断したり, 表

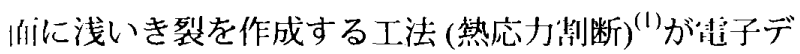
バイスや液晶板などの高ぜい性材の加工に実用化され ている. 熱応力割断の特徵は, 砥石や刃物が不要な非 接触工法であり, 適切な温度上昇の制御により微細き 裂の少ない強じんな断面が得られる点にある(2). 熱源 形状や加熱媒体など, 温度変化の与え方には種々の選 択肢があり，目的に忘じて適切な加熱方法を選ぶこと ができる. 最も基本的な熱応力割断の形態は移動する 熱源を用いるものであり, 熱源から離れた位置に生じ る引張応力がき裂進展を駆動する一方で, 熱源近傍の 压縮応力はき裂進展を制動する，そのためき裂先端は 移動する熱源を後方から追従するように準静的に進展 し, 得られる割断形状は熱源の移動軌跡とほぼ同一と なる.この乖は移動熱源を川いた熱応力制断に限った 特徵ではなく，加熱領域を線状に引き延ばした線割断 の豩合においても，很られる制断形状はほぼ加熱線に 沿う直線となることが数值解析や実験で確認されてい $3^{(3)}$.

与えられた熱エネルギーが弾性体の温度上昇のみに

* 原稿受付 2009 年 3 月 30 日

*1 正員, 長崎大学大学院生産科学研究科( $852-8521$ 長崎市 文教町 1-14)

*2 正員, 長崎大学工学部機械シスデム工学科.

E-mail : s-aki@nagasaki-u.ac.jp
奇与し，温度場とひずみ場の連成効果が無視できる準 静的熱弾性状態では, 温度場は熱伝導方程式を温度境 界条件のもとで解けば求められる。一方, 温度变化に 伴って生じる熱ひずみに対応する応力埸は，一般には 境界における力学的境界条件を満たさない．そこで熱

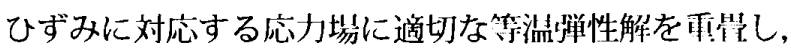
力学的境界条件を満たす解を求めるのが熱弾性問題の 標準的な解法といえる。，さて，境界形状が不変の準静 的熱弾性問題では, 時間依存性は温度場のみに現れる。 数值解析により精度良く温度分布を求めるには十分小 さい時間刻を用いる必要があり, 熱応力問題の計算時 間の大半は温度場計算に費される. 熱源を用いた割断 の問題に限れば, 移動熱源がもたらす熱弾性場を効率 的に評価することが，全体の計算時間の短縮化に大い に寄与する．そこで本研究では，き裂と熱源が種々の 温度境界近傍に存在する場合の熱応力拡大係数を数值 解析して, 応力拡大係数に及ぼす温度境界条件の影響 を調査した，温度境界条件が実際とは異なっていても， 応力拡大係数への影響が小さいならば, 溫度計算に既 知の単純な解を利用するなどの近似計算が可能となり, 計算時䦌を劇的に知縮できる。 また熱源を追従するき 裂の問題では, 明確な温度上昇域は熱源とき裂先端を 含む比較的狭い範囲に限られるので, き裂先端近傍の 温度上昇のみを考慮して熱応力拡大係数を近似計算す る場合の近似の精度についても検討した。 


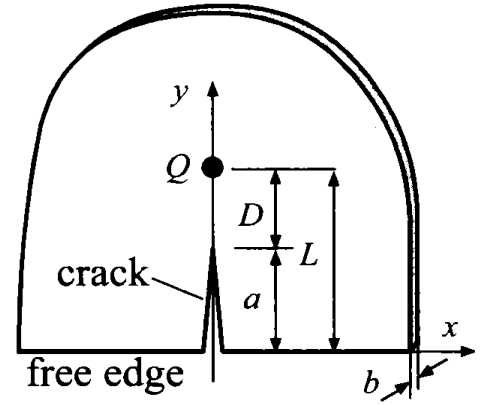

Fig. 1 Semi-infinite plate with edge crack heated by a point heat source

\section{2. 緑き裂の熱応力拡大係数と自由縁の温度境界条件}

2.1 無限板に生じた瞬間点熱源による熱弾性場 厚み $b$ の無限平板内の一点 $(\xi, \boldsymbol{\eta})$ に強さ $d q$ の瞬間 点熱源が時刻 $\tau$ に生じるとき，点 $(x, y)$ における時刻 $t(t>\tau)$ での熱弾性場は熱源の作用点に関して軸対称 であり, 距離 $R=\sqrt{(x-\xi)^{2}+(y-\eta)^{2}}$ を用いて以下 のように表される(4).

$$
\begin{aligned}
T(R, t) & =\frac{d q}{4 \pi b \lambda(t-\tau)} e^{-R^{2} / 4 \kappa(t-\tau)-2 \kappa \gamma(t-\tau) / b \lambda} \\
\sigma_{r}(R, t) & =-\frac{\alpha E}{R^{2}} \int_{0}^{R} T(r, t) r d r \\
\sigma_{\theta}(R, t) & =-\alpha E T(R, t)+\frac{\alpha E}{R^{2}} \int_{0}^{R} T(r, t) r d r
\end{aligned}
$$

ここで $T(R, t), \sigma_{r}(R, t), \sigma_{\theta}(R, t)$ はそれぞれ板厚方向 の平均をとった温度上昇, 半径方向応力, 周方向応力 であり $\alpha$ は線膨張係数， $E$ は縦弾性係数， $\gamma$ は板表面 から大気への放熱を表す熱伝達係数， $\lambda$ は熱伝導率, $\kappa$ は熱拡散係数である. $d q=Q d \tau$ とし，これらを加熱 時刻 $\tau$ で積分すれば持続固定熱源による熱弾性場が, また， $\xi=\xi_{0}+v_{x} \tau ， \eta=\eta_{0}+v_{y} \tau$ のように移動速度を 考慮すると，等速移動する点熱源による熱弾性場を求 めることができる.

さて, 瞬間点熱源の熱弾性場を用いて自由縁から長 さ $a$ のき裂が生じた半無限板に，単位時閏あたりの加 熱エネルギー $Q$ の点熱源が作用する問題 (図 1)を考え る.き裂と熱源の作川点はともに门闫縁とけ交する $y$ 軸上にあり，対称性からモード I の応力特異性のみが 生じる. $y=L$ の位置に固定熱源が作用する場合と, 原 点を始点とし,$y=L$ まで等速度 $v$ で移動する熱源が作 用する場合について, 自由縁の温度境界条件が (a) 断 熱境界 $\left(d T /\left.d y\right|_{y=0}=0\right)$, (b) 等温境界 $\left(\left.T\right|_{y=0}=0\right)$, お よび (c) 温度境界を考慮しない場合について，き裂先 端に生じる応力拡大係数を数值解析した.

条件 (a)では熱源作用点の $x$ 軸に関する鏡像点に同
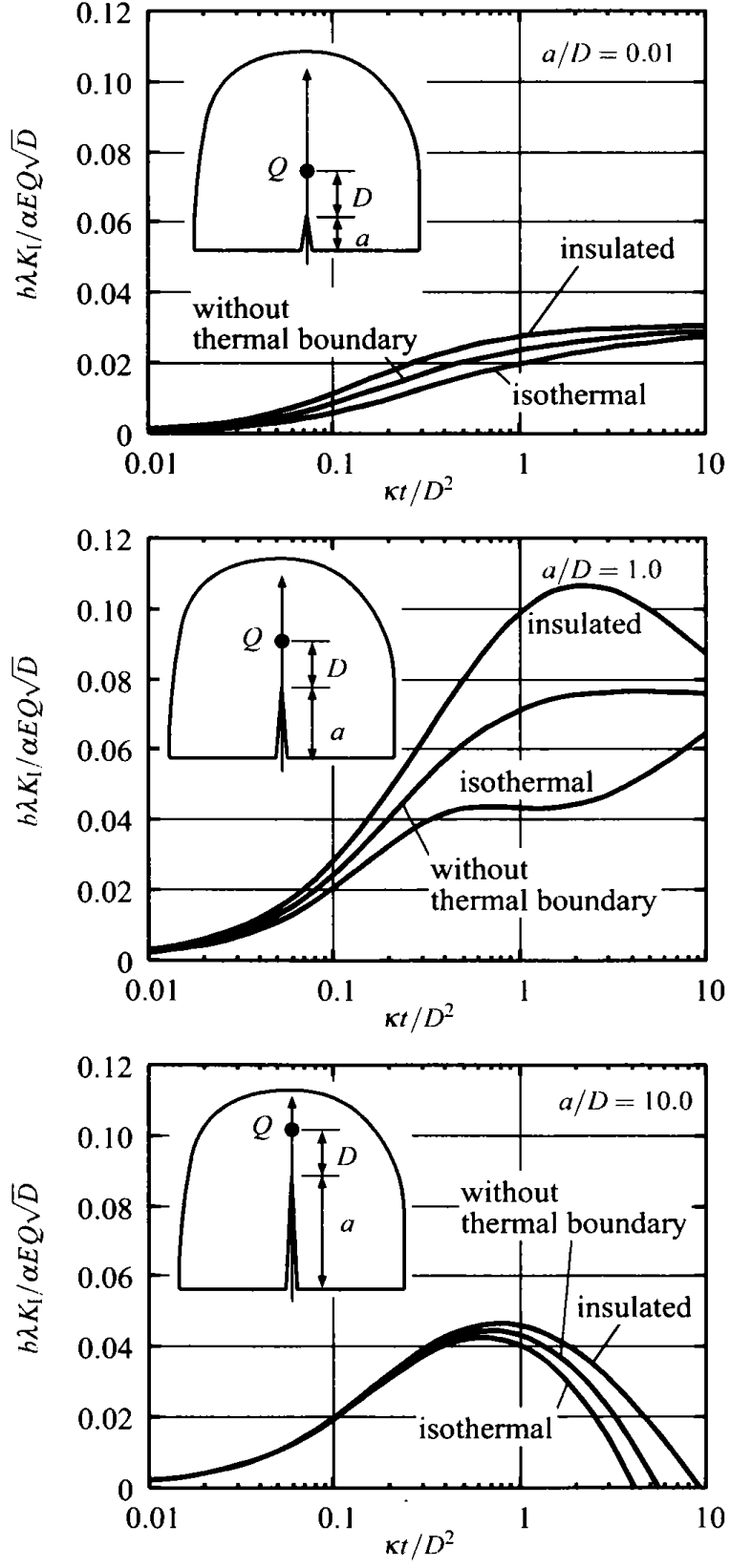

Fig. 2 Thermal stress intensity factor of edge crack duc to a fixed point heat $(\gamma=0.0)$

強度の発熱源が作用する無限板の熱弾性場を, 条件 (b)

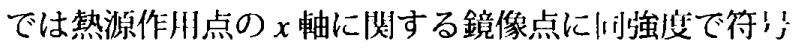
の異なる吸熱源が作用する無限板の熱弾性場を, また, 条件 (c) では無限板の熱弾性場そのものを川いる．す なわち, それぞれの温度境界条件に応じて式 (2) およ び式(3) から算される熱応力埸において，y=0の而 とき裂面に生じる表面力を同時に打ち消して自由表面 とする等温弾性解を考えてき裂先端の応力拡大係数を 求めた。なお，等温弾性問題の解析には体積力法 ${ }^{(5)}$ 用いた。 


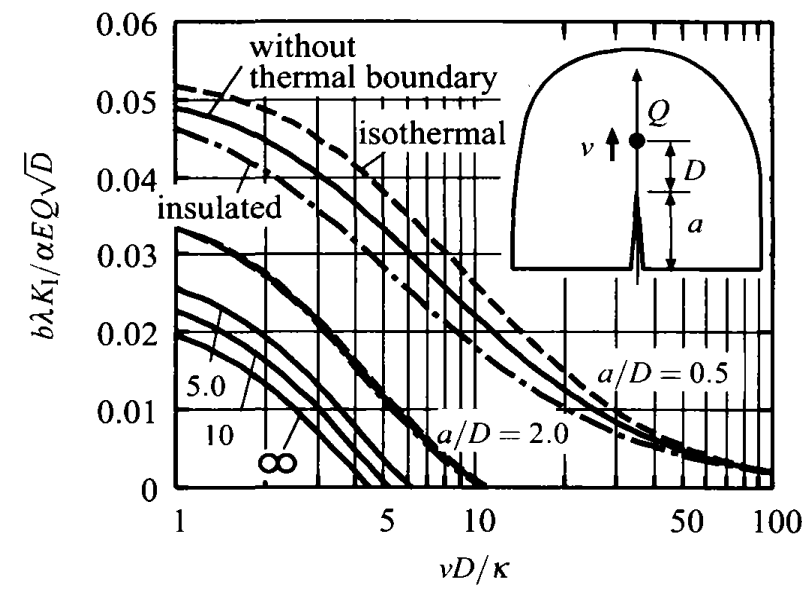

(a) nearly insulated surface $\left(\gamma D^{2} / b \lambda=4.0\right)$

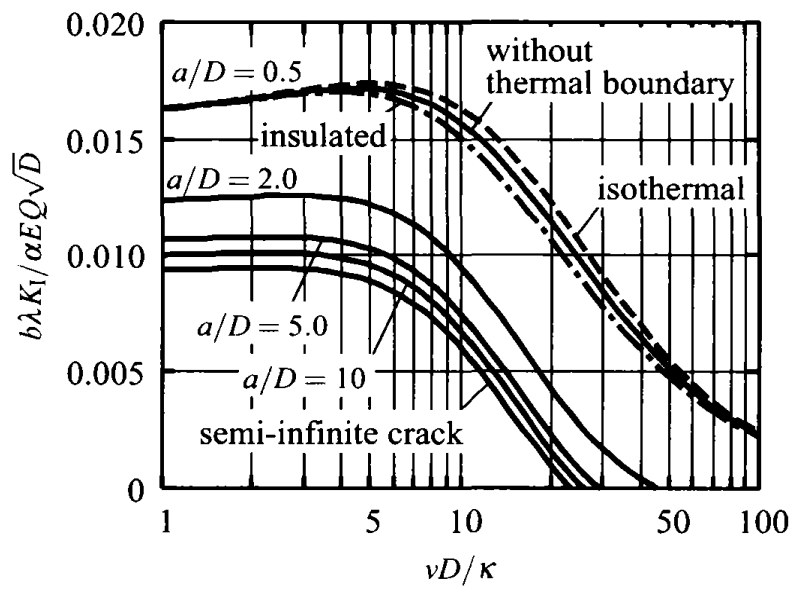

(b) natural heat convection $\left(\gamma D^{2} / b \lambda=20.0\right)$

Fig. 3 Thermal stress intensity factor of edge crack due to a moving point heat

2.2 固定点熱源 図 2 に, 固定熱源の場合にお ける熱応力拡大係数と無次元加熱時間 $\kappa t / D^{2}$ の関係 を，3 種類の無次元き裂長さ $(a / D)$ に対して整理した 結果を示す．固定熱源問題では自由縁に導入した微小 き裂が進展を始めるまでの短い時間範囲を対象とする ので, 洁められた板表直からのけ然放熱は简简のため 無視 $(\gamma=0)$ している. 加熱開始直後の $K_{1}$ は温度境界 条件の造いによらずほぼ|、じ倾向で徐々に滥加するが, $K_{\mathrm{I}}$ の最大値や， $K_{\mathrm{I}}$ が最大となる加熱時間は, き裂長

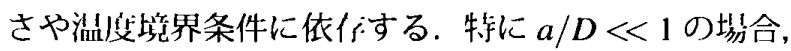
加熱時間が小さい範囲でも 3 種類の温度境界条件に対 する $K_{\mathrm{I}}$ の相対差が大きく, 温度境界条件を正確に指 定しなければ得られる㐫力拡大係数の信頼性が低下す る. なお, 同一の加熱時間で比較すると, 自由縁が断 熱である場合が最大の，等温である場合が最小の $K_{\mathrm{I}}$ を与えていることが分る.

標準的なソーダガラスの熱拡散係数は $\kappa \approx 6.5 \times$ $10^{-7} \mathrm{~m}^{2} / \mathrm{s}$ の程度であり, 炭酸ガスレーザを熱源に用 いる実験室の環境では $D=5 \sim 30 \mathrm{~mm}$ 程の距離で割 断が行われる.この場合, 加熱時間は長くとも数十 秒のオーダーであり，これらの条件は図 2 の横軸で， $\kappa t / D^{2} \approx 0.05$ 程度の值に対応する. 図 2 で 3 種類の温 度境界条件による湆が㫿に表れるのは $\kappa t / D^{2}>0.1$ 以降の範囲であることを考慮すれば，值線縁に垂直に 焱生するき裂の熱応力拡大係数を評価する際には，滥 度境界は存在しないとみなして近似計算しても誤差は 小さいことが理解される.

\section{3 移動点熱源 熱源の無次元移動速度 $\nu D / \kappa$ を} パラメータとし、前節と同様に種々のき裂長さに対す る $K_{\mathrm{I}}$ を解析して网 3 を得た. なお, 移動熱源問題では 板表面からの放熱も重要なパラメータとなる. 例えば
$D=20 \mathrm{~mm}$ で板厚 $b=1 \mathrm{~mm}$ のソーダガラスの割断では, $\gamma D^{2} / b \lambda=20$ は静止大気への自然対流 $\left(\gamma=90 \mathrm{~W} / \mathrm{m}^{2} \mathrm{~K}\right)$ に， $v D / \kappa=10$ は移動速度 $0.33 \mathrm{~mm} / \mathrm{s}$ に相当する. 同 一の $a / D$ に対する応力拡大係数と温度境界条件との 対応関係は固定熱源の場合とは逆になっており，等温 境界で最大の $K_{\mathrm{I}}$ を，断熱境界で最小の $K_{\mathrm{I}}$ を示した。 しかし，き裂がある程度長く $(a / D>2.0)$ なると， $K_{I}$ に及ぼす滥度境界条件の影覒はほぼ無礼できるようで ある，また，板表面からの放熱が小さいと $K_{\mathrm{I}}$ の最大 们は增加する一方で，制断速度を大きくすることに伴 う熱忘力拡大係数の減少率が大きくなり, 高い割断速 度を実現することが困難になる．図 3 にはき裂長さが 無限大の場合の忘力拡大係数 ${ }^{(6)}$ もプロットしたａ/D が大きくなるに従い，無理なく半無限き裂の解に漸近 している.

き裂先端が温度境界から十分に遠ざかれば，自由縁 における温度境界条件の違いがき裂先端の応力拡大係 数に及ぼす影響は当然小さくなる．またこのような場 合には，き裂先端近傍の温度分布のみを用いて直接応 力拡大係数を評価できる可能性があると考えた. そこ で、き裂先端からどの程度離机た範囲までの温度分布 を考慮すれば，十分な精度で熱応力拡大系数を近似計 算できるかについて周尛することとした。

\section{3. 無限小の面積に生じた温度上昇による熱応力場}

初期温度と初期応力がともにゼロの無限板を考え, ある領域 $A$ のみに一様温度上昇 $T_{0}$ が生じた瞬間を考

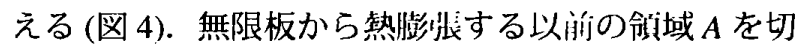
り取り, 領域 $A$ の外周の変位を拘束した状態で温度を

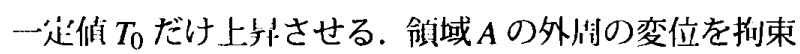
するには，その外周に一定圧打 $p=\beta T_{0}$ を与える必要 


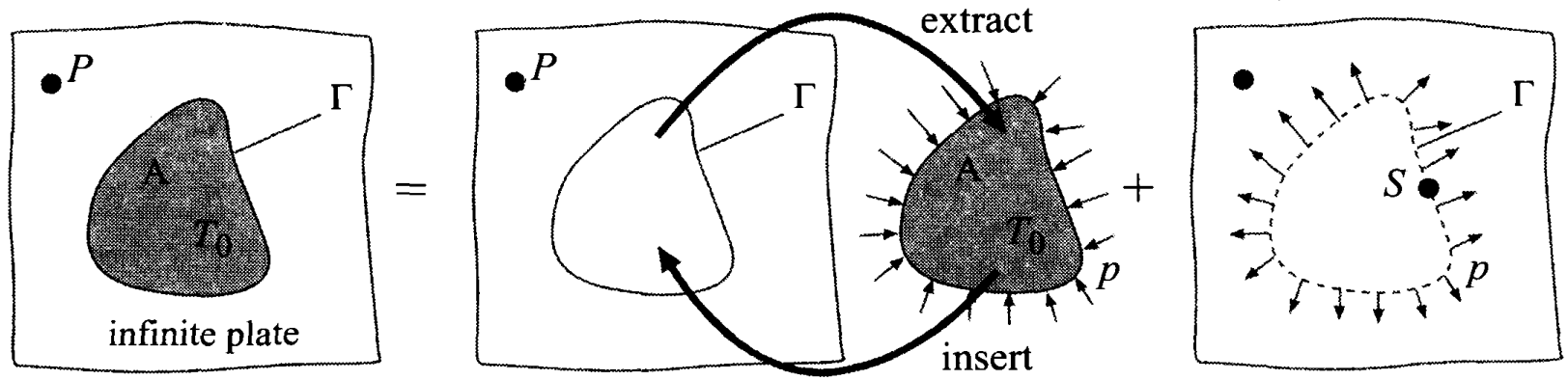

Fig. 4 Analysis of thermal stress by the method of shrink fitting

があり,その絬果 $A$ の内部に静水圧場 $\sigma_{x}=\sigma_{y}=-\beta T_{0}$ が生じる.ここに $\beta$ は線膨張係数 $\alpha$, 縦弾性係数 $E$ お よびポアソン比 $v$ からなる年数 $\beta=\alpha E /(1-v)$ であ る. 次に領域 $A$ を無限板に戻し, $A$ の境界 $\Gamma$ に生じて いる圧力 $p$ を除去するために「に沿って一様な大き さ $p$ の体積力を作用させれば熱膨張ひずみに対応する 熱応力場が得られる. すなわち, 参考点 $P(x, y)$ に生 じる熱态力はテンソルの記号を用いて次のように表さ れる.

$$
\begin{aligned}
\sigma_{i j}(P) & =\beta T_{0} \int_{\Gamma}\left\{\sigma_{i j}\left(P, S_{\xi}\right) \ell+\sigma_{i j}\left(P, S_{\eta}\right) m\right\} d \Gamma(S) \\
& -\beta T_{0} \delta_{i j} \quad \cdots(P \in A)
\end{aligned}
$$

式(4)の右辺第 2 項は拘束を受けながら温度上昇 $T_{0}$ を 経験する領域 $A$ 内の点 $P$ に生じる静水圧場を表すか ら, 点 $P$ が領域 $A$ に属さない場合にはこの項が消滅 して次のように表される.

$$
\sigma_{i j}(P)=\beta T_{0} \int_{\Gamma}\left\{\sigma_{i j}\left(P, S_{\xi}\right) \ell+\sigma_{i j}\left(P, S_{\eta}\right) m\right\} d \Gamma(S)
$$

$\delta_{i j}$ はクロネッカのデルタ記! jであり $, i, j$ は $x$ または $y$ を表す. 点 $S(\xi, \eta)$ は境界 $\Gamma$ 上の動点であり, $S$ の添 ‘奻の作川方向を示す．また $(\ell, m)$ は $S$ における境 界 $\Gamma$ の外向き単位法線べクトルの $x, y$ 成分である. 例 えば $\sigma_{x x}\left(P, S_{\xi}\right)$ は無限板中の一点 $S$ に $\xi$ 方向の単位集 中力が作用するときに参考点 $P$ に生じる $\sigma_{x}$ を，また $\sigma_{x x}\left(P, S_{\eta}\right)$ は無限板中の一点 $S$ に $\eta$ 方向の単位集中力 が作用するときに参考点 $P$ に生じる $\sigma_{x}$ を意味する.

領域 $A$ に生じている温度上昇が一定值 $T_{0}$ ではなく, 座標の関数 $T(x, y)$ である場合には, $A$ をその内部で温 度が一様とみなせるほど小さい領域 $\delta A$ に分割し，そ れらの影響を重ね合わせれば良い，このとき，微小領 域 $\delta A$ の外周に作用する体積力は互いに接近して力対 を形成する.そこで温度分布が存在するときの熱応力
の社算式 $(P \in A)$ は以下のようになる.

$$
\begin{aligned}
\sigma_{i j}(P) & =\beta \int_{A}\left\{\sigma_{i j, \xi}\left(P, S_{\xi}\right)+\sigma_{i j, \eta}\left(P, S_{\eta}\right)\right\} T(S) d A(S) \\
& -\beta T(P) \delta_{i j} \quad \cdots(P \in A)
\end{aligned}
$$

コンマに続く座標変数はその変数による偏微分を表し，

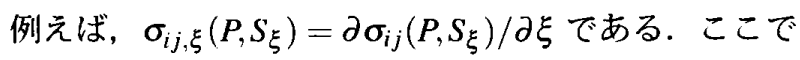

$$
\sigma_{i j, k}\left(P, S_{k}\right) T(S)=\frac{\partial \sigma_{i j}\left(P, S_{k}\right) T(S)}{\partial k}-\sigma_{i j}\left(P, S_{k}\right) T_{, k}(S)
$$

の関係 $(k=\xi, \eta)$ を用い, 式 (6) の第 1 項に発散定理 を適川すると，次式が後られる。

$$
\begin{aligned}
\sigma_{i j}(P) & =\beta \int_{\Gamma}\left\{\sigma_{i j}\left(P, S_{\xi}\right) \ell+\sigma_{i j}\left(P, S_{\eta}\right) m\right\} T(S) d \Gamma(S) \\
& -\beta \int_{A}\left\{\sigma_{i j}\left(P, S_{\xi}\right) \frac{\partial T}{\partial \xi}+\sigma_{i j}\left(P, S_{\eta}\right) \frac{\partial T}{\partial \eta}\right\} d A(S) \\
& -\beta T(P) \delta_{i j} \quad \cdots(P \in A)
\end{aligned}
$$

Duhamel の朴似这理によれば，㴓度上け! $T(x, y)$ を うけた二次元平板内の熱忘力は，境界に仮想表面力 $t_{x}=\beta T \ell, t_{y}=\beta T m$ が, また，领域内に仮想物体力 $f_{x}=-\beta(\partial T / \partial x), f_{y}=-\beta(\partial T / \partial y)$ が作用する等温弾 性問題を解き, その結果に静水圧 $\sigma_{x}=\sigma_{y}=-\beta T$ を 加えたものとして計算でき(7)，式 (7) は Duhamel の相 似定理そのものを表していることが理解される．ただ し，式 (7) を用いると温度とその公配の分布が熱応力 計算に必要となるのに対し，式(6)では温度分布のみ で熱応力が計算できることになる.

なお，二次元問題における力対の応力場は注目点 と観測点の距離 $R$ に対して $1 / R^{2} \sigma$ 特異性を持つので $P \in A$ の場合には式 (6) を次のように変形する.

$$
\begin{aligned}
\sigma_{i j}(P) & =\beta \int_{A}\left\{\sigma_{i j, \xi}\left(P, S_{\xi}\right)+\sigma_{i j, \eta}\left(P, S_{\eta}\right)\right\} \\
& \times(T(S)-T(P)) d A(S) \\
& +\beta T(P) \int_{A}\left\{\sigma_{i j, \xi}\left(P, S_{\xi}\right)+\sigma_{i j, \eta}\left(P, S_{\eta}\right)\right\} d A(S) \\
& -\beta T(P) \delta_{i j} \quad \ldots(P \in A)
\end{aligned}
$$


そして式 (8)の右辺第 2 項に再び発散定理を適用して

$$
\begin{aligned}
\sigma_{i j}(P) & =\beta \int_{A}\left\{\sigma_{i j, \xi}\left(P, S_{\xi}\right)+\sigma_{i j, \eta}\left(P, S_{\eta}\right)\right\} \\
& \times(T(S)-T(P)) d A(S) \\
& +\beta T(P) \int_{\Gamma}\left\{\sigma_{i j}\left(P, S_{\xi}\right) \ell+\sigma_{i j}\left(P, S_{\eta}\right) m\right\} d \Gamma(S) \\
& -\beta T(P) \delta_{i j} \quad \ldots(P \in A)
\end{aligned}
$$

式(9)の右辺第 1 项では $P$ と $S$ が一致する場合の特䝨 性が除去されており, 観測点が温度上舁範囲にあって も通常の数值積分により熱応力場が計算できる. なお, 陳ら ${ }^{(8)}$ は弾塑性解析に拡張された体積力法において, 力対の領域積分における特異性の処理方法に関して詳 細な議論を展開している。

式 (6) の右辺第 1 項は, 点 $S$ に生じる単位大きさの 膨張中心 $(x$ および $y$ 方向の強さが等しい力対)による 応力場を, その点の温度 $T(S)$ を重みとして面積積分 することを表している. 従って, 点 $S$ を含む微小面積 $\delta A$ に生じた一様温度上昇 $T_{0}$ が， $\delta A$ に含まれない点 $P$ に及ぼす熱応力の寄与分は，大きさ $\beta T_{0}$ の膨版中心 による弾性場と同一で次のように表される.

$$
\delta \sigma_{i j}(P)=\beta T_{0}\left\{\sigma_{i j, \xi}\left(P, S_{\xi}\right)+\sigma_{i j, \eta}\left(P, S_{\eta}\right)\right\} \delta A
$$

二次元弾性問題の解は複素応力関数で表すと便利な ことが多く, $i$ を虚数単位とし, 観測点 $P$ を表す複 素変数 $z=x+i y$ と, 温度上昇点 $S$ を表す複素変数 $z_{0}=\xi+i \eta$ を導入すると，無限平板に対して式 (10) を与える Goursat 型の複素㐫力関数は式 (11) で与えら 扎る。

$$
\delta \Omega(z)=0, \delta \omega(z)=-\frac{\alpha E T_{0} \delta A}{2 \pi\left(z-z_{0}\right)}
$$

什し, 複采応力関数がリえられれば応力成分は次の関 係から求められる(9).

$$
\begin{aligned}
\delta\left(\sigma_{x}+\sigma_{y}\right) & =2\left\{\delta \Omega^{\prime}(z)+\overline{\delta \Omega^{\prime}(z)}\right\} \\
\delta\left(\sigma_{y}-\sigma_{x}+2 i \tau_{x y}\right) & =2\left\{\bar{z} \delta \Omega^{\prime \prime}(z)+\delta \omega^{\prime}(z)\right\}
\end{aligned}
$$

無限小の面積の温度上昇による熱応力の寄与分を複素 応力関数で表したことにより，例えば単純形状のき裂 を有する無限板内の微小面積に温度変化が生じたこと

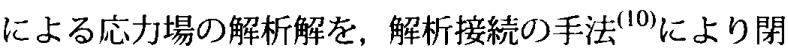
じた形で求めることができる.

例えば， $x$ 軸上の範囲 $|x|<a$ に表面力自由なき裂を 持つ無限板において, 点 $z_{0}$ を命む微小伯積 $\delta A$ に生じ た温度上昇 $T_{0}$ がき裂先端 $(+a, 0)$ に生じる応力拡大係 数への奇' $j$ 分は式(14)のように，また， $T$ ストレスへ の奇与分は式 (15)のように求められる.

$$
\begin{gathered}
\delta\left(K_{\mathrm{l}}+i K_{\mathrm{II}}\right)=\frac{\alpha E T_{0} \delta A \sqrt{a}}{2 \sqrt{\pi}\left(z_{0}-a\right) \sqrt{z_{0}^{2}-a^{2}}} \\
\delta \sigma_{T}=-\frac{\alpha E T_{0} \delta A}{2 \pi}\left\{\frac{1}{\left(z_{0}-a\right)^{2}}+\frac{1}{\left(\overline{z_{0}}-a\right)^{2}}\right\}
\end{gathered}
$$

これらの式でき裂先端 $(a, 0)$ を原点とする啝座槽を川 い, 温度上昇位置を $z_{0}=a+r e^{i \theta}$ で表すと，

$$
\begin{gathered}
\delta\left(K_{\mathrm{I}}+i K_{\mathrm{II}}\right)=\frac{\alpha E T_{0} \delta A e^{-3 i \theta / 2}}{2 \sqrt{2 \pi} r^{1.5}} \sqrt{\frac{2 a}{2 a+r e^{i \theta}}} \\
\delta \sigma_{T}=-\frac{\alpha E T_{0} \delta A}{\pi r^{2}} \cos 2 \theta
\end{gathered}
$$

半無限き裂の場合は式 (16)で $a \rightarrow \infty$ として,

$$
\delta\left(K_{\mathrm{I}}+i K_{\mathrm{II}}\right)=\frac{\alpha E T_{0} \delta A}{2 \sqrt{2 \pi} r^{1.5}}\left(\cos \frac{3 \theta}{2}-i \sin \frac{3 \theta}{2}\right)
$$

き裂先端近傍に任意の温度上昇 $T(r, \theta)$ が生じている場 合は，温度を重みとして式(16)，あるいは (18)を積分 して応力搪大係数を概算することができる，例えば式 (16) に基づいて応力拡大係数を求める際は $\delta A=r d r d \theta$ とおいて面積積分した式(19)を用いる.

$$
\begin{aligned}
& K_{\mathrm{I}}+i K_{\mathrm{II}}=\int_{A} \delta\left(K_{\mathrm{I}}+i K_{\mathrm{II}}\right)=\frac{\alpha E}{2 \sqrt{2 \pi}} \times \\
& \lim _{R^{*} \rightarrow \infty} \int_{0}^{R^{*}} \int_{-\frac{\pi}{2}}^{\frac{\pi}{2}} \frac{T(r, \theta)}{\sqrt{r}} e^{-\frac{3}{2} i \theta} \sqrt{\frac{2 a}{2 a+r e^{i \theta}}} d r d \theta
\end{aligned}
$$

図 5 に式(17), (18) で表す応力拡大係数と $T$ ストレ スへの寄与分の等強度線図を示す。横軸は温度上昇点

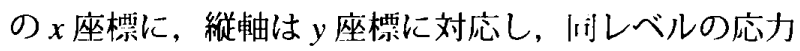
拡大係数と $T$ ストレスが得られる温度上昇位置が曲 線で絬ばれている，KI が正となる領域はき裂先端朔方 に存在し， $x$ 軸を挟んで $\pm 60^{\circ}$ の間にある，逆にその 他の領域では㵿度を低下させれば正の $K_{\mathrm{I}}$ が得られる. また， $K_{\mathrm{II}}$ はき裂面を境としてその符号が逆転してい る. $K_{\mathrm{I}}$ の場合と併せて考えれば，き裂先端前方の比較 的狭い領域に高温域が，き裂面を含む広い領域に低温 域が存在するよう温度分布を制御すれば大きな $K_{1} か ゙$ 得られ, 効率的な熱応力割断が行える.

図 5から分るように熱忘力拡大係数に強く影響する 温度上昇範囲はき裂先端の近傍に限られる，また，熱 源による温度変化の場合など温度上昇が狭い範囲に留 まる問題では式 (19) で半径方向の積分上界を有限值 に留めても埕差は少ないと考えられる. そこで式(19) で $R^{*}$ を枋限に留めた近似解の精度について検封した。

3.1 無限板の熱応力割断問題における熱応力拡大 係数の近似計算 $x$ 軸に沿って長さ $2 a$ のき裂を持 つ無限板が，き裂先端からDだけ離れた位萣に阔远さ れた熱源によって $t$ 秒間加熱される場合を考える. 板 


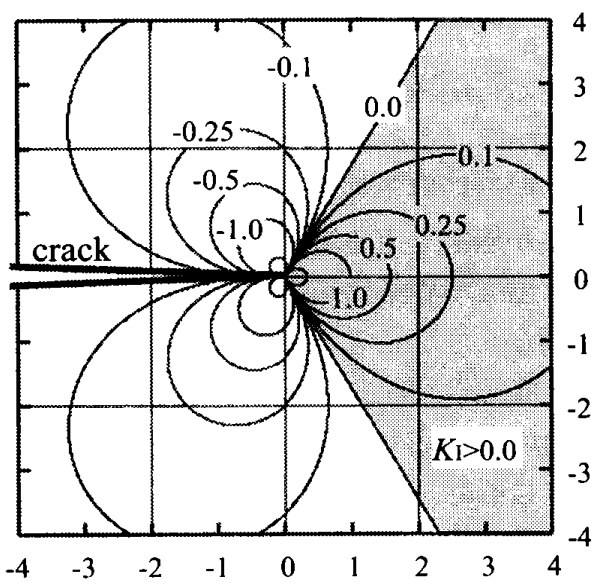

(a) Contour of $2 \sqrt{2 \pi} \delta K_{\mathrm{I}} / \alpha E T_{0} \delta A$

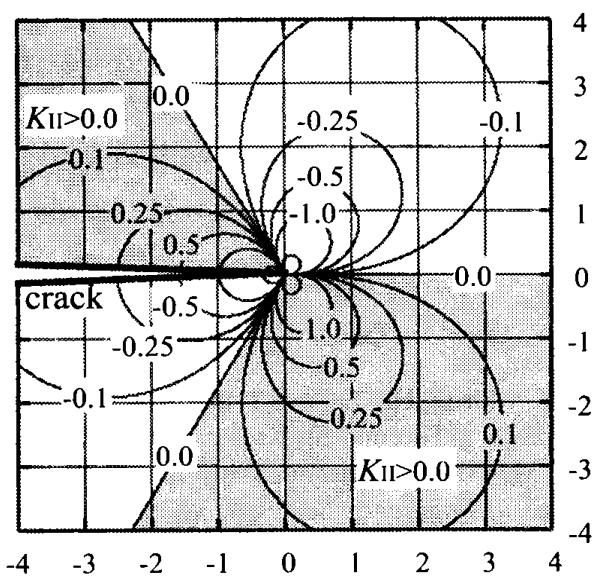

(b) Contour of $2 \sqrt{2 \pi} \delta K_{\mathrm{II}} / \alpha E T_{0} \delta A$

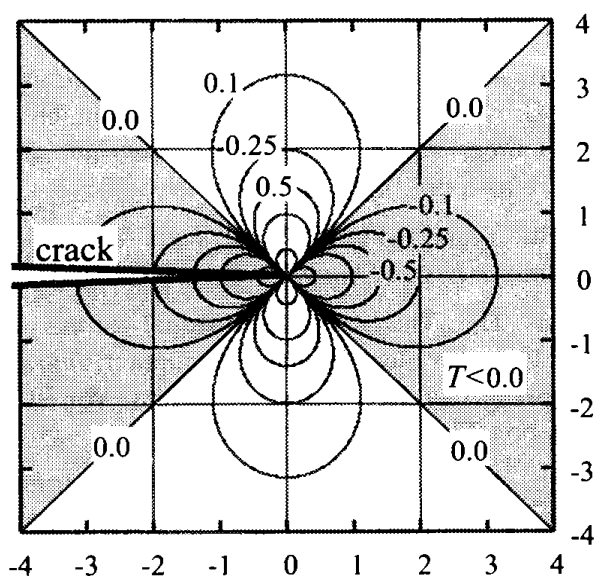

(c) Contour of $\pi \delta \sigma_{\gamma} / \alpha E T_{0} \delta A$

Fig. 5 Contour plots of stress intensity factors and

$T$-stress for semi-infinite crack $(x<0, y=0)$ due to a temperature rise $T_{0}$ at an infinitesimal area $\delta A$

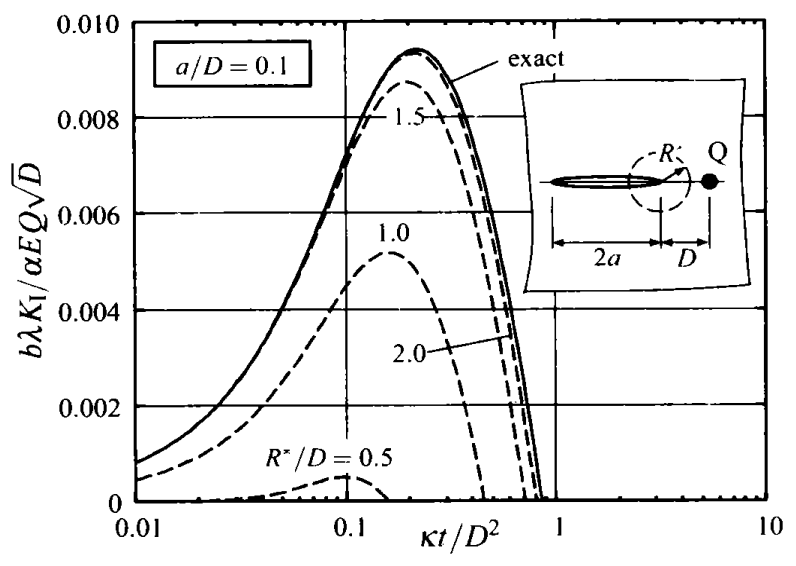

(a) Short crack situation $(a / D=0.1)$

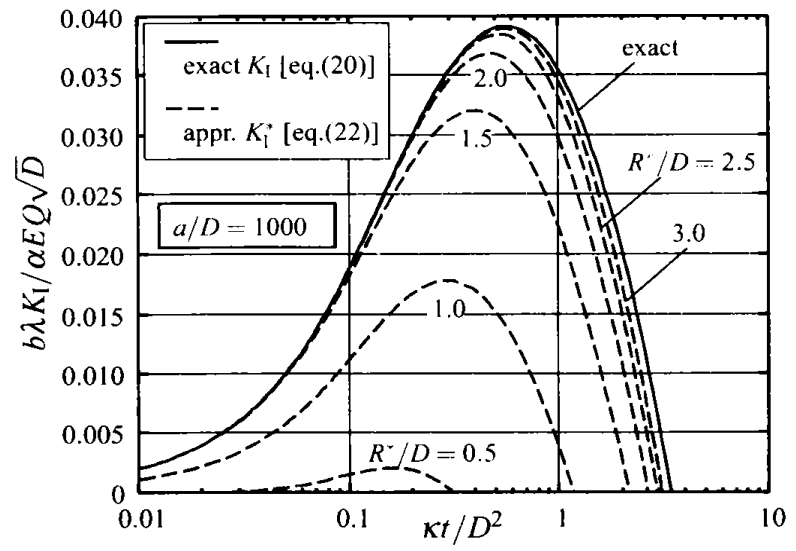

(b) Long crack situation $(a / D=1000)$

Fig. 6 Evaluation of approximated $K_{\mathrm{I}}$ formula for fixed heat source $(\gamma=0)$

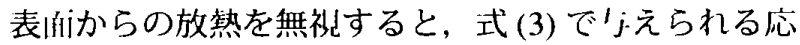
力分布を考慮して，き裂面が表面力自由となる条件か ら求めたき裂先端 (熱源僛)の $K_{\mathrm{I}}$ の敞密解は式 (20)で 与えられる。

$$
K_{\mathrm{I}}=\frac{\alpha E Q}{8 \pi b \lambda} \int_{-a}^{a} \sqrt{\frac{a+\xi}{a-\xi}}\left\{\frac{1-e^{-S}}{S}-E_{\mathrm{I}}(S)\right\} \frac{d \xi}{\sqrt{\pi a}}
$$

ここで $S=(D+a-\xi)^{2} / 4 \kappa t$ であり, $E_{1}(S)$ は積分指 数㩆数で

$$
E_{1}(S)=\int_{S}^{\infty} \exp (-x) \frac{d x}{x}
$$

で定義される．また $Q$ は単位時間あたりの加熱エネル ギーである，次に式 (19)で $R^{*}$ を有限とした近似解は 次のように書ける.

$$
K_{\mathrm{I}}^{*}=\frac{\alpha E}{2 \sqrt{2 \pi}} \int_{0}^{R^{*}} \int_{-\frac{\pi}{2}}^{\frac{\pi}{2}} \Re\left[\frac{T(r, \theta) e^{-3 i \theta / 2}}{\left.\sqrt{r\left(1+r e^{i \theta} / 2 a\right.}\right)}\right] d r d \theta
$$




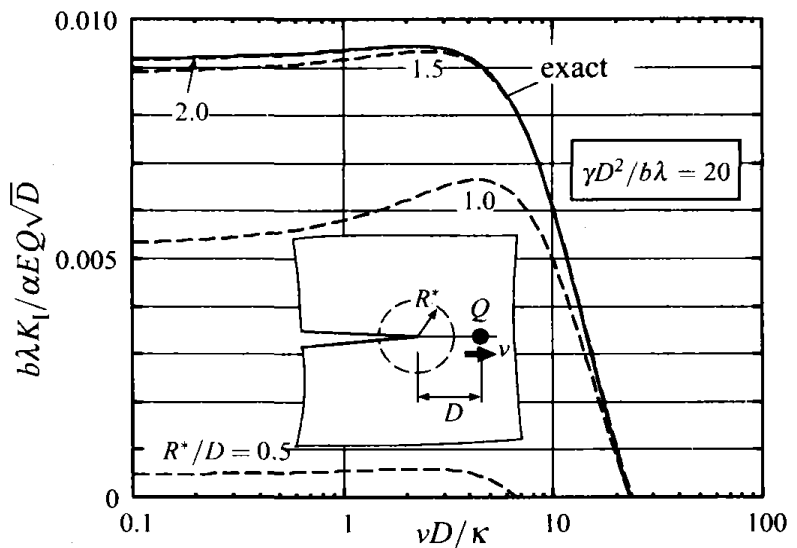

Fig. 7 Evaluation of approximated $K_{1}$ formula for moving heat source $\left(\gamma D^{2} / b \lambda=20\right)$

ここで は夷部を表し， $T(r, \theta)$ は次式で与えられる.

$$
T(r, \theta)=\frac{Q}{4 \pi b \lambda} E_{1}\left(\frac{r^{2}+D^{2}-2 r D \cos \theta}{4 \kappa t}\right)
$$

図 6 に式(20) および式 (22) から得られる $K_{\mathrm{I}}$ の)比較 を示す. 図中奏線は式 (20) の厳密解を表し, 点線は式 (22)において $R^{*} / D$ を 0.5 刻で増加させながら近似解 $K_{I}^{*}$ を求めたものである. 極めて長い加熱時間では近 似精度が覀くなるが， $R^{*} / D>2.5$ でき裂長さに依存せ ずほぼ正確な応力拡大係数が得られている. 図 6 は板 表面の熱伝達を無視した結果であるが, 放熱を考慮す れば熱源から離れた位置での温度上昇が抑制されるた め式 (22)の近似精度はさらに広上する.

以上の議論は移動熱源にも適用できる. 図7に $x$ 軸 上を等速度 $v$ で移動する熱源から距離 $D$ 後方の位置で 熱源を造従する半無限き裂先端の応力拡大係数の解析 例を示す。半無限き裂の問題では式 (22) で $a \rightarrow \infty$ の 楜限をとり， $T(r, \theta)$ として式 (24) を䏳いば良い.

$$
\begin{aligned}
& T(r, \theta)=\frac{Q}{2 \pi b \lambda} \exp \left\{\frac{v(D-r \cos \theta)}{2 \kappa}\right\} \\
& \times K_{0}\left(\sqrt{\left(\frac{r^{2}}{D^{2}}+1-2 \frac{r}{D} \cos \theta\right)\left(\frac{v^{2} D^{2}}{4 \kappa^{2}}+\frac{\gamma D^{2}}{b \lambda}\right)}\right)
\end{aligned}
$$

ここで $K_{0}(x)$ はゼロ次の変形ベッセル関数であり, 次 式で这䉝される。

$$
K_{0}(x)=\int_{0}^{\infty} \exp \left(-u-x^{2} / 4 u\right) \frac{d u}{2 u}
$$

移動熱源問題では熱源が温度境界に極めて近い場合を 除けば，忍力拡大係数はほぼ温度境界条件と無関係と なり，広い範囲の移動熱源問題で式 (24)の温度場が利 用できる. しかも，式(22)に基づいて得られる応力拡 大係数の近似值は，き裂先端を原点として $R^{*} / D<2.0$ の範囲の温度上昇を考慮すると奏用上十分な精度に達 する.

\section{4. 結言}

半無限板の自由縁と直交するき裂に対し，き裂先端 近傍に熱源が作归する場合の応力拡大係数を解析した. 自由境界の温度境界条件として断熱，等温，および温 度境界条件が無視できる場合について䒓祭し、移動熱 源問題では温度境界条件を無視しても応力拡大係数に 及ぼす影響が小さいことを示した。

さらに，直線き裂を有する無限板内の--·点が温度変 化した場合の弾性応力場を複素応力関数で表して，き 裂先端に生じる応力拡大係数の理論解を導いた．また， き裂先端近傍の微小領域の温度上昇に着目し，温度上 昇から直接応力拡大係数を求める近似式を提案した.

温度上昇に基づく応力拡大係数の近似式を数值的に 検討した結果，静止熱源問題に対してはき裂先端を中 心とし熱源とき裂先端との距離の 2.5 倍の半径内の温 度上与を，移動熱源䦌題ではき裂先端を中心とし熱源 とき裂先端との距離の 2.0 倍の半径内の温度上昇をそ れぞれ考勴すると，点啲に十分な精度で応力拡大係 数が求まることが分った.

\section{文献}

(1) Imai, Y., Morita, H., Takase, T. and Koga, H., Possibility of Employing Thermal Stresses as a Cutting Device for Brittle Materials, Transactions of the Japan Society of Mechanical Engineers, Series A, Vol.55, No.509 (1989), pp.147-151.

(2) Sawada, H., Imai, Y. and Saimoto, A., Thermal Stress Cleaving of a Thin Strip Using a Line Heat Source, Journal of the Japan Society of Precision Engineering, Vol.64, No.2 (1998), pp.302-306.

(3) Saimoto, A., Imai, Y. and Motomura, F., Simulation of Crack Growth in Thermal Stress Cleaving Using Line Heat Source, JSME International Journal, Series A, Vol.42, No.4 (1999), pp.578-584.

(4) Takeuchi, Y. and Noda, N., Analysis of Thermal Stresses (4th edition), Nissin Shuppan Ltd., (1989), pp.168-172.

(5) Nisitani, H., The Two-Dimensional Stress Problem Solved Using an Electric Digital Computer, Journal of the Japan Society of Mechanical Engineers, Vol.70, No.580 (1967), pp.627-635.

(6) Saimoto, A., Imai, Y. and Morita, H., Thermal Stress Intensity Factor of Semi-Infinite Crack due to Crack Face Heating, Transactions of the Japan Society of Mechanical Engineers, Series A. Vol.62, No.597 (1996), pp.11721179.

(7) $\mathrm{pp} .41$ of reference (4).

(8) Chen, D.-H. and Nisitani, H., Extension of Body Force Method to Elastic-Plastic Problems, Transaction of the Japan Society of Mechanical Engineers, Series A, Vol.51, No.462 (1985), pp.571-578.

(9) England, A. H., Complex Variable Methods in Elasticity, John Wiley \& Sons Ltd., (1971), pp.32-34.

(10) pp.77-81 of reference (9). 